\title{
Influence of Sowing Season and Host Crop Identity on the Community Structure of Arbuscular Mycorrhizal Fungi Colonizing Roots of Two Different Gramineous and Leguminous Crop Species
}

\author{
Masao Higo*, Katsunori Isobe, Yukiya Matsuda, Mio Ichida, Yoichi Torigoe \\ College of Bioresource Sciences, Nihon University, Fujisawa, Japan \\ Email: " higo.masao@nihon-u.ac.jp
}

Received 20 January 2015; accepted 8 February 2015; published 12 February 2015

Copyright (C) 2015 by authors and Scientific Research Publishing Inc.

This work is licensed under the Creative Commons Attribution International License (CC BY). http://creativecommons.org/licenses/by/4.0/

(c) (7) Open Access

\begin{abstract}
Introduction of cover crops may improve the diversity of arbuscular mycorrhizal fungi (AMF) in roots and soil under crop rotational systems; therefore, it is necessary to determine the potential for AMF communities to improve sustainable food production. We investigated the impact of cover crops, including wheat (Triticum aestivum L.), barley (Hordeum vulgare L.), pea (Pisum sativum L.), and hairy vetch (Vicia villosa Roth.), on the AMF communities in their roots in autumn and spring sowing seasons with PCR-DGGE analysis. Although all four cover crops impacted the AMF community structure in roots, the diversity of AMF communities was unchanged among crop type or sowing season. Redundancy analysis (RDA) demonstrated that AMF communities within crop type were significantly different. However, the AMF community structures were not influenced by growing season, suggesting that growth stage in crops may be more responsive to shaping AMF community structure in crop roots than host crop identity.
\end{abstract}

\section{Keywords}

Arbuscular Mycorrhizal Fungi, Community Structure, Crop Identity, Host Selectivity, Sowing Season

\footnotetext{
${ }^{*}$ Corresponding author.
} 


\section{Introduction}

Arbuscular mycorrhizal fungi (AMF) are widespread in most terrestrial ecosystems where they form mutualistic associations with the majority of plants to facilitate nutrient uptake from the soil via an extensive extraradical mycelium [1]. This symbiotic relationship is present in most agricultural crops, with benefits of increased plant productivity [2], improved soil structure [3] and increased pathogen resistance [4]. Improvement in phosphorus (P) uptake and plant growth by AMF has been documented in many crop plants [5] [6]. Moreover, AMF abundance or diversity is important to overall plant productivity and stability of terrestrial ecosystems [7]. Because of their importance in terrestrial ecosystems, AMF communities have been extensively studied both in natural [8][10] and agricultural settings [11]-[13].

Introduction of mycorrhizal crops, such as pea (Pisum sativum L.), oat (Avena sativa L.), hairy vetch (Vicia villosa Roth.), and wheat (Triticum aestivum L.), in crop rotational system has been shown to maintain or increase AMF biomass, or P uptake and yield in subsequent crops [5] [6] [14]-[16]. The difference in AMF spore density after mycorrhizalcropping has been also shown to be much higher than after non-mycorrhizal cropping [17] or fallow [18]. Winter cover crops such as barley (Hordeum bulbosum L.), wheat, white clover (Trifolium repens L.) and other crops in rotation with summer crops have been used to enhance soil health and fertility [19] [20]. Arranging crop rotation with cover crops may maintain or increase P uptake and yield of subsequent crops [5] [6] [16]. However, Vandenkoornhuyse et al. [21] [22] and Torrecillas et al. [23] have mentioned that there is mounting evidence on host compatibility between host plant and some AMF species. Gosling et al. [11] have also determined presence of a subtle difference in the communities of AMF colonizing roots of two crops, corn (Zea mays L.) and soybean (Glycine max L.) grown in a crop rotational system in the United Kingdom. Alguacil et al. [24] have described the differences between root AMF communities of two agricultural crop species (Jatropha curcas and Ricinus communis) in a tropical system in Guantanamo (Cuba).

Temporal and seasonal variations among AMF communities in plant roots and soil have been shown [23]-[25]. Liu et al. [26] (2009) reported that the composition of AMF communities colonizing Caragana korshinskii roots was not different at the same sampling time, whereas subtle differences in the AMF communities were found in different months. In Japan, Isobe et al. [27] found that Gigasporales was not found in the roots of soybean grown in a cooler region, whereas they were detected in the roots of soybean grown in a temperate region. Isobe et al. [27] suggested that one partial reason for the differences in AMF communities was climate conditions, especially temperature. From these results, it appears that composition or diversity of AMF communities in roots is not necessarily determined only by host selectivity. Yet, there is a paucity of information regarding which environmental factors, such as climate, soil quality and chemical conditions, or host crop identity most strongly influences the differences observed in AMF communities colonizing crop roots. This information is important because AMF abundance or diversity is imperative to overall productivity and stability of agroecosystem functioning in crop rotational systems. Knowledge of seasonal or temporal variation of AMF communities in roots and soil under crop rotational systems would allow us to more effectively arrange crop rotations in agricultural systems and to improve diversity and abundance of AMF communities.

To better capture seasonal or temporal variation of AMF communities under crop rotational systems, we hypothesized that two graminaceous (wheat and barley) and leguminous crop (pea and hairy vetch) species, which are often introduced in rotation with summer crops in autumn or spring, may lead to a shift in AMF diversity or community structure colonizing roots of these crops in the autumn and spring seasons. To test this hypothesis, we investigated the diversity of AMF communities in roots of these four different crop species in the autumn or spring sowing seasons. The innovative aspects of the present study focused on using molecular techniques to determine AMF community structure to assess the impacts of host species and sowing season.

\section{Materials and Methods}

\subsection{Experimental Design}

A pot experiment using a volcanic ash soil (Allophanic and sol, sandy loam texture) was conducted in an experimental field at Nihon University, in Kanagawa, Japan $\left(35^{\circ} 22^{\prime} \mathrm{N}\right.$ and $\left.139^{\circ} 27^{\prime} \mathrm{E}\right)$. To investigate the impact of host crop identity or sowing season on AMF community structure, 1/2000a Wagner pots were prepared with three replicates and mix-cropped with pea (Pisum sativum L., cv: Akabanakinusaya), hairy vetch (Vicia villosa Roth., cv: Mamesuke), wheat (Triticum aestivum L., cv: Bandowase), and barley (Hordeum vulgare L., cv: 
Ichibanboshi). In the autumn sowing, seeds were sown in the same pot on 27 October, 2012. Similarly, in the spring sowing, seeds were sown in the same pot on 13 April, 2013. In both autumn and spring experiments, the number of seeds sown in pea, hairy vetch, wheat and barley was 3, 3, 5 and 5 seeds per pot, respectively. The amounts of $\mathrm{N}$ (ammonium sulfate) and $\mathrm{K}$ (potassium chloride) applied were 3.6 and $1.3 \mathrm{~g}$ per pot, respectively.

\subsection{Soil Sampling and Measurement of Soil Chemical Properties}

Soil samples were collected from each pot on 26 October, 2012, and on 12 April, 2013, before cover crop cultivation. After air-drying, the composite soil samples were passed through a $2 \mathrm{~mm}$ sieve, and stored at $4^{\circ} \mathrm{C}$ until measurement of AMF spore density. Soil pH among each cover crop ranged from 5.8 to 6.4 and available $\mathrm{P}$ content (Bray P) ranged between 30.4 to $48.5 \mathrm{mg}$ per kg dry soil. Total carbon (C) and nitrogen (N) ranged from $6.6 \%$ to $7.1 \%$ and $0.55 \%$ to $0.63 \%$, respectively. AMF spore density ranged from 6.4 to 7.1 spores per g dry soil.

\subsection{Root Sampling, Staining and DNA Extraction}

Root samples of each crop were taken on 14 May, 2013. Root samples were stained with $0.05 \%$ (w/v) try pan blue [28], and AMF colonization in the crop roots was calculated as described by [29].

DNA extractions (five pieces of 1- to 2-cm-long root fragments) were performed using CTAB (Cetyltrimethyl ammonium bromide) method. The DNA pellet was washed once with $80 \%$ ethanol, dried, resuspended in $50 \mu 1$ of tris-ethylenediaminetetraacetic acid (EDTA) (TE) buffer [10 mM Tris- $\mathrm{HCl}(\mathrm{pH}$ 8.0) and $1 \mathrm{mM}$ EDTA (pH 8.0)], and stored at $-30^{\circ} \mathrm{C}$ until used for polymerase chain reaction (PCR).

\subsection{Nested PCR}

The DNA samples per replicate extracted from roots were used as PCR templates after 20-fold dilution. The DNA pellet was resuspended in $50 \mu \mathrm{l}$ of TE buffer [10 mM Tris- $\mathrm{HCl}(\mathrm{pH}$ 8.0) and $1 \mathrm{mM}$ EDTA (pH 8.0)], and stored at $-30^{\circ} \mathrm{C}$ until use for PCR. The DNA samples extracted from roots were used as PCR templates after 10fold dilution. The amplification of a region in the fungal small subunit ribosomal DNA (SSU rDNA) was conducted using a nested PCR method [30]. The fungus-specific primers AM1 (5'-GTTTCCCGTAAGGCGCCGAA-3') [31] and the universal eukaryotic primer NS31 (5'-TTGGAGGGCAAGTCTGGTGCC-3') [32] were used in the first PCR to amplify the 5' end of the SSU rDNA region. PCR was performed in a $25 \mu$ l reaction mixture containing $1 \mu \mathrm{l}$ of template DNA, $0.2 \mu \mathrm{M}$ of each primer, and GoTaq Green Master Mix (Promega, Madison, WI, USA) using a thermal cycler (Mastercycler ep Gradient, Eppendorf, Hamburg, Germany). The PCR protocol was composed of an initial treatment at $94^{\circ} \mathrm{C}$ for $1 \mathrm{~min}$; 30 cycles of treatments at $94^{\circ} \mathrm{C}$ for $1 \mathrm{~min}, 66^{\circ} \mathrm{C}$ for 1 min, and $72^{\circ} \mathrm{C}$ for $1 \mathrm{~min} 30 \mathrm{~s}$; and a final treatment at $72^{\circ} \mathrm{C}$ for $10 \mathrm{~min}$. The first PCR products were diluted 100 -fold and used as templates for the second PCR using the nested primers NS31-GC

(5'-CGCCCGGGGCGCGCCCCGGGCGGGGCGGGGGCACGGGGGTTGGAGGGCAAGTCTGGTGCC-3') [33] and Glo1 (5'-GCCTGCTTTAAACACTCTA-3') [34]. PCR was performed in a $50 \mu$ reaction mixture containing $2 \mu \mathrm{l}$ of template DNA, $0.2 \mu \mathrm{M}$ of each primer, and 2× GoTaq Green Master Mix (Promega, Madison, WI, USA) using Mastercycler ep Gradient (Eppendorf, Hamburg, Germany). The PCR protocol was composed of an initial treatment at $95^{\circ} \mathrm{C}$ for $5 \mathrm{~min} ; 35$ cycles of treatments at $94^{\circ} \mathrm{C}$ for $45 \mathrm{~s}, 52^{\circ} \mathrm{C}$ for $45 \mathrm{~s}$, and $72^{\circ} \mathrm{C}$ for 1 min; and a final treatment at $72^{\circ} \mathrm{C}$ for $30 \mathrm{~min}$. Amplification products were separated by gel electrophoresis on $1 \%$ agarose gel in Tris-acetate-EDTA (TAE) buffer ( $40 \mathrm{mM}$ Tris, pH 8.0, $40 \mathrm{mM}$ acetic acid and $1 \mathrm{mM}$ EDTA) and DNA was visualized by staining with ethidium bromide.

\subsection{PCR-DGGE}

Twenty microliters of nested PCR product was subsequently analyzed by DGGE on DCode Universal Mutation Detection System (Bio-Rad Laboratories, Piscataway, NJ, USA). The gels containing 6.5\% acrylamide were poured with a gradient of 35\% - 55\% denaturant. All DGGE analysis was performed in $1 \times$ TAE buffer at a constant temperature of $55^{\circ} \mathrm{C}$ at $50 \mathrm{~V}$ for $60 \mathrm{~min}$, followed by $50 \mathrm{~V}$ for $960 \mathrm{~min}$ using the modified protocol of Liang et al. [30]. The gels were then stained with SYBR Green diluted in 1× TAE buffer (1:10,000) for 20 min, UV illuminated and digitally photographed. Pictures were captured and digitized by Phoretix 1D Pro (Nonlinear Dynamics Ltd., Newcastle upon Tyne, UK). 


\subsection{Molecular Diversity of AMF Communities in Cover Crop Roots}

From the data we calculated AMF DGGE band richness, expressed by the number of DGGE bands in each root sample. The Shannon diversity index of each treatment was calculated as an additional measure of AMF diversity.

\section{Statistical Analysis}

To analyze the relatedness of sampling plots with respect to AMF community structure (AMF communities), a preliminary detrended correspondence analysis (DCA) on the presence/absence matrix per DGGE band was also performed. This result was summarized in an ordination diagram using the vegan package version 2.0 - 10 in $R$ 3.0.2. DCA indicated (the length of gradient $>4$ ) that at least some species had a unimodal distribution. Redundancy analysis (RDA, length of gradient $<4$ ) as multivariate analysis was performed. The data matrix was composed of the presence/absence of DGGE bands and crop type. During the RDA procedure, Monte Carlo 999 permutation test for significance at $P<0.05$ was used.

Climate data were compiled from the Japan Meteorological Agency (http://www.jma.go.jp/jma/indexe.html).

\section{Results}

Climate factors, including precipitation, average temperature, accumulated temperature, and sunshine duration from sowing to sampling time differed between autumn and spring sowing season (Table 1). Cumulative precipitation in autumn and spring sowing season from sowing to sampling time was 750.5 and 88.5 mm, and average temperature was $11.5^{\circ} \mathrm{C}$ and $15.9^{\circ} \mathrm{C}$, respectively. Accumulated temperature was $1945.1^{\circ} \mathrm{C}$ and $494.1^{\circ} \mathrm{C}$, and sunshine duration was 1022.6 and 234.3 hour, respectively.

In this study, AMF root colonization in each cover crop was unchanged among crop types and sowing season (Figure 1). Significant differences were observed only among crop type. In contrast, the number of DGGE bands or band patterns were different among crop types in the autumn sowing (Figure 2 and Figure 3), but not in the spring sowing. In autumn mix-cropping, the number of DGGE bands was highest in barley and lowest in hairy vetch, although this was not the case in spring mix-cropping. The diversity index $\left(H^{\prime}\right)$ (number of DGGE bands) showed similar trends across all the treatments. The results of two-way ANOVA showed that crop type, but not sowing season, affected the number of DGGE bands. However, the diversity index was not influenced by crop type and sowing season.

Table 1. Climate conditions from sowing to sampling in this study.

\begin{tabular}{ccccc}
\hline Treatment & $\begin{array}{c}\text { Cumulative precipitation } \\
(\mathrm{mm})\end{array}$ & $\begin{array}{c}\text { Average temperature } \\
\left({ }^{\circ} \mathrm{C}\right)\end{array}$ & $\begin{array}{c}\text { Accumulated temperature } \\
\left({ }^{\circ} \mathrm{C}\right)\end{array}$ & $\begin{array}{c}\text { Sunshine duration }(\mathrm{h}) \\
\text { Autumn sowing }\end{array}$ \\
Spring sowing & 750.5 & 11.5 & 1945.1 & 4022.6 \\
\hline
\end{tabular}

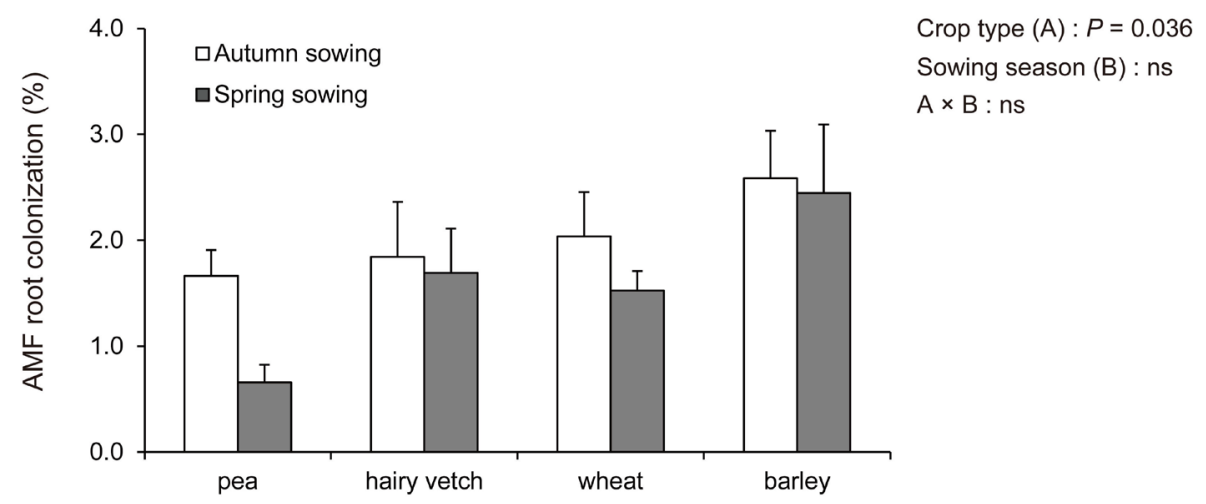

Figure 1. AMF root colonization in the four different crops sown in autumn and spring season. Vertical bars represent the mean $( \pm$ S.E). 

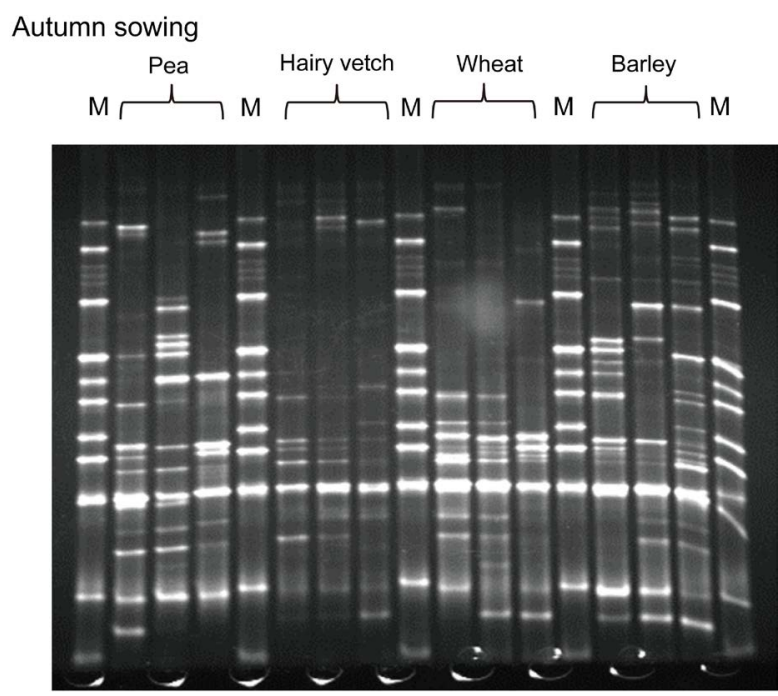

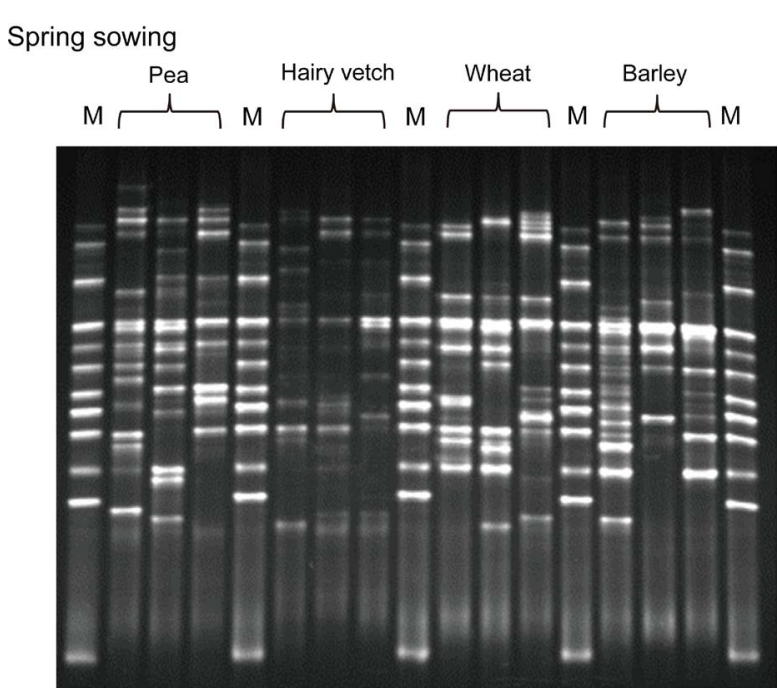

Figure 2. PCR-DGGE band patterns of AMF communities in the roots of four different crops sown in autumn and spring season. M: marker.
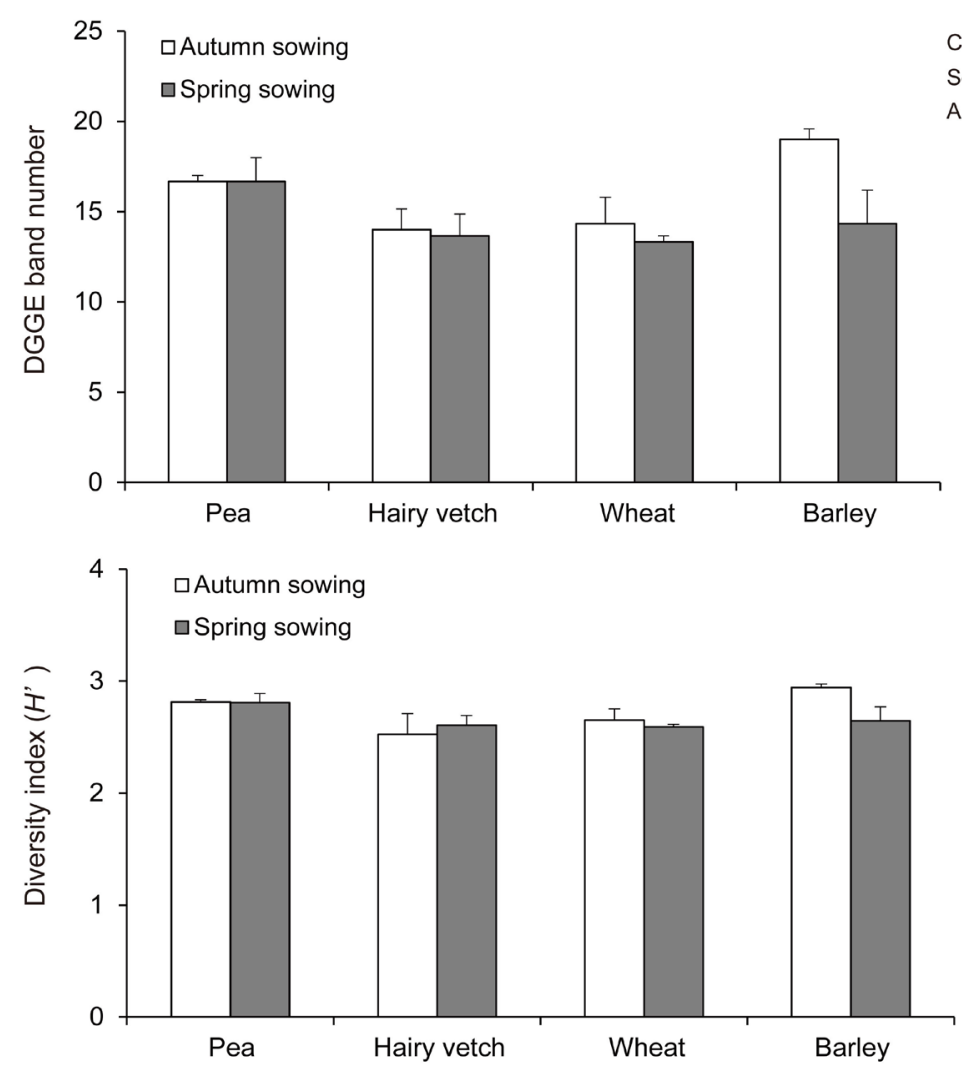

Figure 3. Molecular diversity of AMF communities in the roots of four different crops sown in autumn and spring season. Vertical bars represent the mean $( \pm$ S.E). ns: not significant.

RDA was used to identify relationships between AMF communities in the cover crop roots and crop type (Figure 4) and sowing season (Figure 5). A Monte-Carlo permutation test indicated that the relationship between AMF communities in the cover crop roots and crop type was significantly influenced by autumn sowing ( $F=2.247, P=0.001$ ), but not spring sowing $(F=1.087, P=0.287)$. Pea (autumn sowing: $R^{2}=0.925, P=$ 0.009 , spring sowing: $R^{2}=0.690, P=0.008$ ) and hairy vetch (autumn sowing: $R^{2}=0.940, P=0.006$, spring 

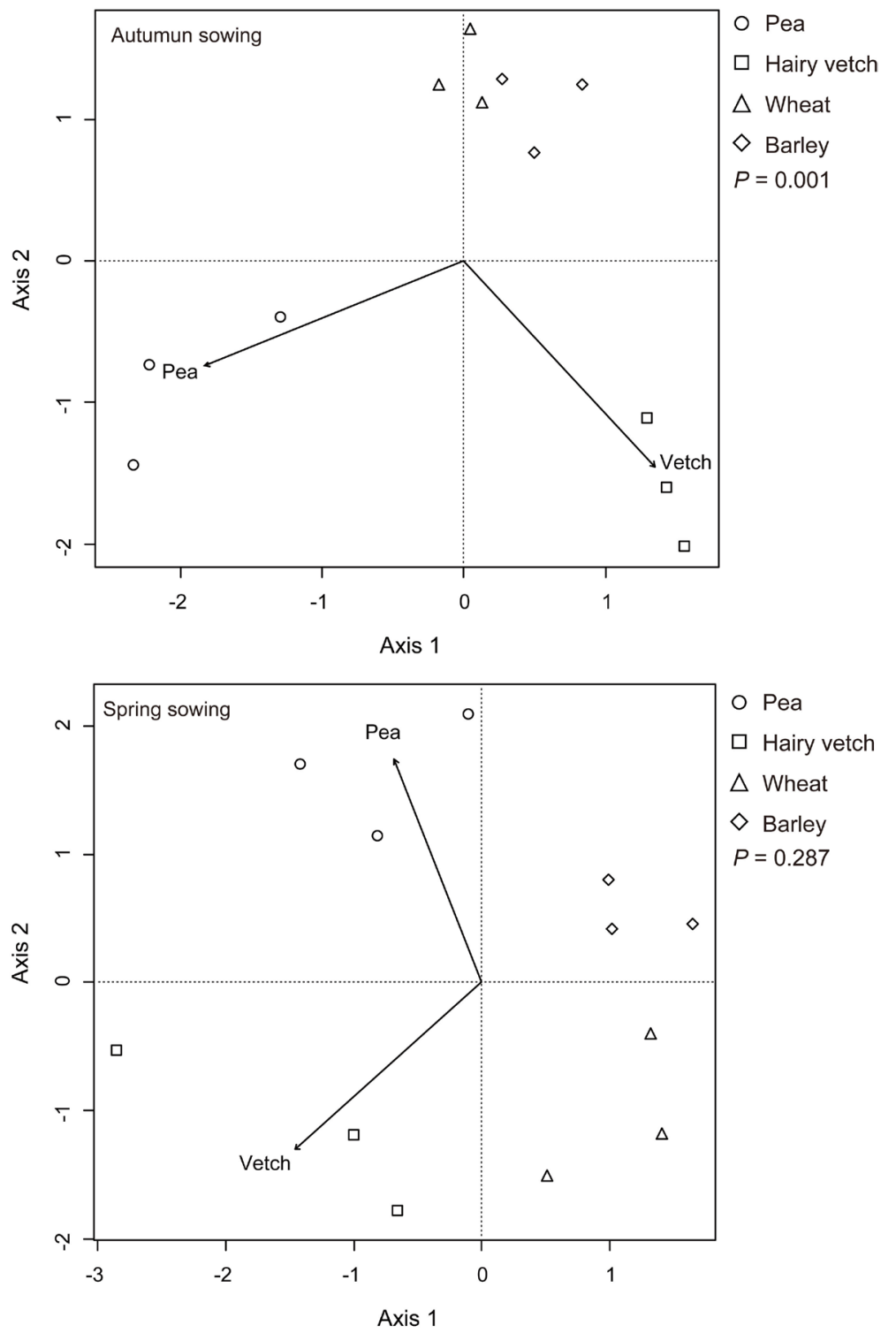

Figure 4. Redundancy analysis (RDA) biplot showing relationship between detected DGGE bands and crop type. In autumn sowing, the eigenvalues of the first and second axes were 7.230 and 3.845, respectively. In spring sowing, the eigenvalues of the first and second axes were 3.390 and 2.707, respectively. The only significant variables $(P<0.05)$ such as pea and hairy vetch were shown in this figure.

sowing: $R^{2}=0.757, P=0.008$ ) contributed significantly to the variation in AMF communities in cover crop roots under both sowing seasons (Figure 4). Also, RDA was used to identify relationships between AMF communities in cover crop roots and sowing season (Figure 5). A Monte-Carlo permutation test indicated that the relationship between AMF communities in cover crop roots and sowing season was highly significant $(F=$ $4.570, P=0.001)$.

\section{Discussion}

In this study we examined the differences in root AMF communities of four different cover crops, i.e., pea, hairy vetch, wheat, and barley, grown in two different sowing seasons (autumn and spring). Our results indicated that host identity clearly drove the specific difference in root AMF communities of the four crops when they were autumn-sown (Figure 3), and this is in agreement with previous studies [11] [23]. There is mounting evidence 


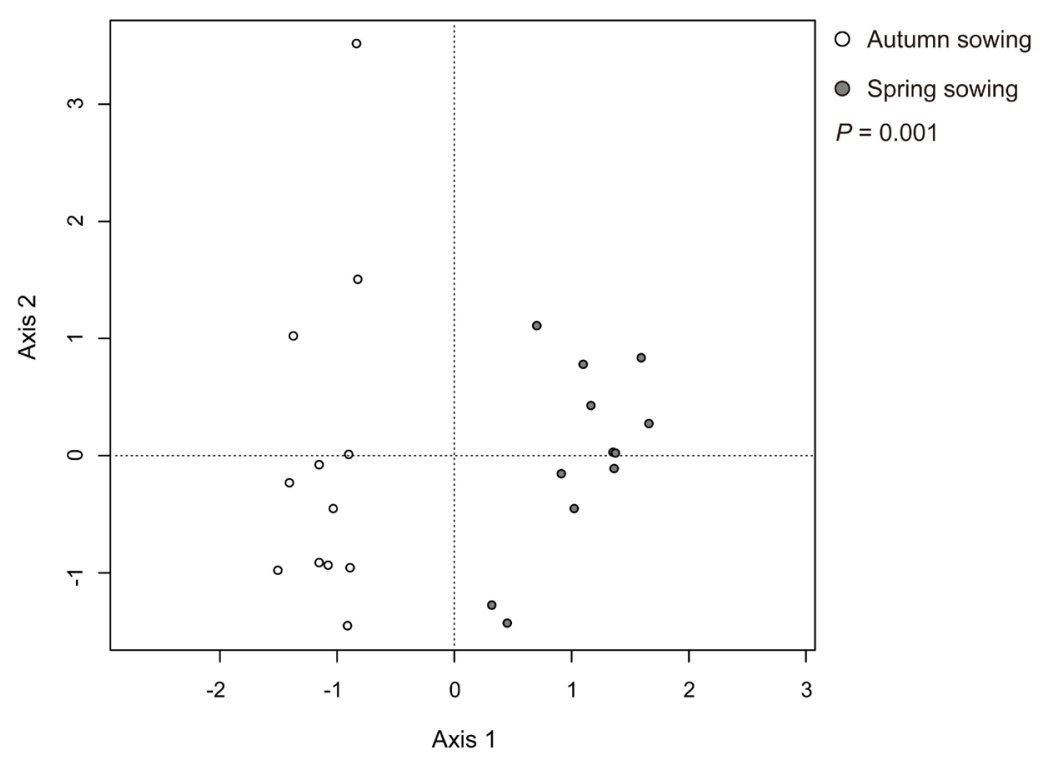

Figure 5. Redundancy analysis (RDA) biplot showing relationship between detected DGGE bands and sowing season. The eigenvalues of the first and second axes were 6.020 and 4.098 , respectively.

that host selectivity exists among plants and AMF [23] [35] and our results add to that body of evidence. The main reason for the difference in root AMF communities in each cover crop appears to some extent to be related to host selectivity or host preference between the cover crops and indigenous AMF in our field soil. Host identity did not affect the AMF communities when the crops were spring-sown, and the reasons for this are not clear. This consistency in AMF communities colonizing the roots of our four spring-sown crops was somewhat unexpected. In previous studies, Broeckling et al. [36] have shown that plant root exudates drove the shift of soil microbial communities, with the difference in the AMF communities influenced by specific root exudate patterns of each cover crop. We hypothesize that one reason for the consistency in AMF communities among the springsown cover crops may be weakened effects of specific root exudate patterns on AMF communities due to the early growth stage. Further research would be needed to better understand whether crop growth stage, time of year, or other abiotic environmental factors strongly influence AMF diversity or community structure in winter cover crop rotational systems.

For autumn-sown crops, our results demonstrated that sowing season clearly drove the specific difference in the root AMF communities of pea, hairy vetch, wheat and barley (Figure 4). It has been shown that the dominant AMF population is likely to shift as the environment changes over time [13] [25] [37]. Dumbrell et al. [38] have reported presence of significant differences in AMF communities and diversity between cooler and warmer periods of the year in temperate environments. Veresoglou et al. [39] have also indicated that precipitation was a key determinant that affected the presence or absence of Gigasporales. Furthermore, Higo et al. [13] have shown that the diversity of AMF communities in a 5-year soybean rotational system with winter cover crops was negatively correlated with cumulative precipitation, or positively correlated with maximum or mean temperature during the growing period. Moreover, AMF communities colonizing soybean roots were clearly influenced by rotation year, suggesting that climate or other environmental factors were more important than winter cropping system management. Therefore, we would expect that an extended time course trial might have elucidated the determining factors governing the relationships between host identity and AMF community structure and diversity.

Furthermore, host preference to AMF in leguminous crops can be higher than that in gramineous crops, because gramineous crops have the potential to take up large amounts of $\mathrm{P}$ from soil because of their higher root volume and root hair development [40] [41]. Root volume and hair length is much less in leguminous crops compared with that in gramineous crops so they are highly dependent on symbiosis with AMF to take up large of amounts of P from soil [42] [43]. In addition, Scheublin et al. [44] noted that the preferential association of different AMF species with legumes compared with non-leguminous plants was different. The structure and function of the root system are also expected to influence how plants respond to colonization by AMF [1]. For 
these results, one predictable reason for the difference in the AMF communities of the four crop roots might be the root system architecture and the extent of root growth development among the four crops.

\section{Conclusion}

In conclusion, our study has shown that host crop identity impacts AMF communities only in roots of the four autumn-sown cover crops. Host identity has traditionally been considered as a strong factor in shaping AMF communities in plant roots [11] [21] [22]. Our results suggest that host crop identity may not be such a strong factor in determining AMF communities in roots of cover crops, and that abiotic environmental factors such as climate, growing season, geographical region, or agricultural management may be more important. Also, crop biomass may mediate AMF communities in soil and roots. A clear understanding of the function of AMF to P nutrition in cover crop rotational systems would be needed to investigate how we currently manage these systems, particularly crop rotation decisions.

\section{References}

[1] Smith, S.E. and Read, D.J. (2008) Arbuscular Mycorrhizaes. In Smith, S.E. and Read, D.J., Eds., Mycorrhizal Symbiosis, 3rd Edition, Academic Press, London.

[2] Lekberg, Y. and Koide, R.T. (2005) Is Plant Performance Limited by Abundance of Arbuscular Mycorrhizal Fungi? A Meta-Analysis of Studies Published between 1988 and 2003. New Phytologist, 168, 189-204. http://dx.doi.org/10.1111/j.1469-8137.2005.01490.x

[3] Piotrowski, J.S., Denich, T., Klironomos, J.N., Graham, J.M. and Rillig, M.C. (2004) The Effects of Arbuscular Mycorrhizae on Soil Aggregation Depend on the Interaction between Plant and Fungal Species. New Phytologist, 164, 365-373. http://dx.doi.org/10.1111/j.1469-8137.2004.01181.x

[4] Sikes, B.A., Cottenie, K. and Klironomos, J.N. (2009) Plant and Fungal Identity Determines Pathogen Protection of Plant Roots by Arbuscular Mycorrhizas. Journal of Ecology, 97, 1274-1280. http://dx.doi.org/10.1111/j.1365-2745.2009.01557.x

[5] Oka, N., Karasawa, T., Okazaki, K. and Takebe, M. (2010) Maintenance of Soybean Yield with Reduced Phosphorus Application by Previous Cropping with Mycorrhizal Plants. Soil Science of Plant Nutrition, 56, 824-830. http://dx.doi.org/10.1111/j.1747-0765.2010.00518.x

[6] Njeru, E.M., Avio, L., Sbrana, C., Turrini, A., Bocci, G., Bàrberi, P. and Giovannetti, M. (2014) First Evidence for a Major Cover Crop Effect on Arbuscular Mycorrhizal Fungi and Organic Maize Growth. Agronomy and Sustainable Development, 34, 841-848. http://dx.doi.org/10.1007/s13593-013-0197-y

[7] van der Heijden, M.G.A., Klironomos, J.N., Ursic, M., Moutoglis, P., Streitwolf-Engel, R., Boller, T., Wiemken, A. and Sanders, I.R. (1998) Mycorrhizal Fungal Diversity Determines Plant Biodiversity, Ecosystem Variability and Productivity. Nature, 396, 69-72. http://dx.doi.org/10.1038/23932

[8] Lumini, E., Orgiazzi, A., Borriello, R., Bonfante, P. and Bianciotto, V. (2010) Disclosing Arbuscular Mycorrhizal Fungal Biodiversity in Soil through a Land-Use Gradient Using a Pyrosequencing Approach. Environmental Microbiology, 12, 2165-2179.

[9] Lekberg, Y., Schnoor, T., Kjøller, R., Gibbons, S.M., Hansen, L.H., Al-Soud, W.A., Sorensen, S.J. and Rosendahl, S. (2012) 454-Sequencing Reveals Stochastic Local Reassembly and High Disturbance Tolerance within Arbuscular Mycorrhizal Fungal Communities. Journal of Ecology, 100, 151-160. http://dx.doi.org/10.1111/j.1365-2745.2011.01894.X

[10] Xiang, D., Verbruggen, E., Hu, Y., Veresoglou, S.D., Rillig, M.C., Zhou, W., Xu, T., Li, H., Hao, Z., Chen, Y. and Chen, B. (2014) Land Use Influences Arbuscular Mycorrhizal Fungal Communities in the Farming-Pastoral Ecotone of Northern China. New Phytologist, 204, 968-978. http://dx.doi.org/10.1111/nph.12961

[11] Gosling, P., Mead, A., Proctor, M., Hammond, J.P. and Bending, G.D. (2013) Contrasting Arbuscular Mycorrhizal Communities Colonizing Different Host Plants Show a Similar Response to a Soil Phosphorus Concentration Gradient. New Phytologist, 198, 546-556. http://dx.doi.org/10.1111/nph.12169

[12] Bainard, L.D., Bainard, J.D., Hamel, C. and Gan, Y. (2014) Spatial and Temporal Structuring of Arbuscular Mycorrhizal Communities Is Differentially Influenced by Abiotic Factors and Host Crop in a Semi-Arid Prairie Agroecosystem. FEMS Microbiology Ecology, 88, 333-344. http://dx.doi.org/10.1111/1574-6941.12300

[13] Higo, M., Isobe, K., Drijber, R.A., Kondo, K., Yamaguchi, M., Takeyama, S., Suzuki, Y., Niijima, D., Matsuda, Y., Ishii, R. and Torigoe, Y. (2014) Impact of a 5-Year Winter Cover Crop Rotational System on the Molecular Diversity of Arbuscular Mycorrhizal Fungi Colonizing Roots of Subsequent Soybean. Biology and Fertility of Soils, 50, 913-926. http://dx.doi.org/10.1007/s00374-014-0912-0 
[14] Buyer, J.S., Teasdale, J.R., Roberts, D.P., Zasada, I.A. and Maul, J.E. (2010) Factor Affecting Soil Microbial Community Structure in Tomato Cropping Systems. Soil Biology and Biochemistry, 42, 831-841. http://dx.doi.org/10.1016/j.soilbio.2010.01.020

[15] Lehman, R.M., Taheri, W.I., Osborne, S.L., Buyer, J.S. and Douds, D.D. (2012) Fall Cover Cropping Can Increase Arbuscular Mycorrhizae in Soils Supporting Intensive Agricultural Production. Applied Soil Ecology, 61, 300-304. http://dx.doi.org/10.1016/j.apsoil.2011.11.008

[16] Isobe, K., Higo, M., Kondo, T., Sato, N., Takeyama, S. and Torigoe, Y. (2014) Effect of Winter Crop Species on Arbuscular Mycorrhizal Fungal Colonization and Subsequent Soybean Yields. Plant Production Science, 17, $260-267$. http://dx.doi.org/10.1626/pps.17.260

[17] Karasawa, T. and Takebe, M. (2012) Temporal or Spatial Arrangements of Cover Crops to Promote Arbuscular Mycorrhizal Colonization and P Uptake of Upland Crops Grown after Nonmycorrhizal Crops. Plant and Soil, 353, 355366. http://dx.doi.org/10.1007/s11104-011-1036-z

[18] Higo, M., Isobe, K., Yamaguchi, M., Drijber, R.A., Jeske, E.S. and Ishii, R. (2013) Diversity and Vertical Distribution of Indigenous Arbuscular Mycorrhizal Fungi under Two Soybean Rotational Systems. Biology and Fertility of Soils, 49, 1085-1096. http://dx.doi.org/10.1007/s00374-013-0807-5

[19] Altieri, M.A. (1999) The Ecological Role of Biodiversity in Agroecosystems. Agriculture, Ecosystems \& Environment, 74, 19-31. http://dx.doi.org/10.1016/S0167-8809(99)00028-6

[20] Reddy, K.N., Zablotowicz, R.M., Locke, M.A. and Koger, C.H. (2003) Cover Crop, Tillage, and Herbicide Effects on Weeds, Soil Properties, Microbial Populations, and Soybean Yield. Weed Science, 51, 987-994. http://dx.doi.org/10.1614/P2002-169

[21] Vandenkoornhuyse, P., Husband, R., Daniell, T.J., Watson, I.J., Duck, J.M., Fitter, A.H. and Young, J.P.W. (2002) Arbuscular Mycorrhizal Community Composition Associated with Two Plant Species in a Grassland Ecosystem. Molecular Ecology, 11, 1555-1564. http://dx.doi.org/10.1046/j.1365-294X.2002.01538.X

[22] Vandenkoornhuyse, P., Ridgeway, K., Watson, I.J., Fitter, A.H. and Young, J.P.W. (2003) Co-Existing Grass Species Have Distinctive Arbuscular Mycorrhizal Communities. Molecular Ecology, 12, 3085-3095. http://dx.doi.org/10.1046/j.1365-294X.2003.01967.x

[23] Torrecillas, E., Alguacil, M.M. and Roldán, A. (2012) Host Preferences of Arbuscular Mycorrhizal Fungi Colonizing Annual Herbaceous Pant Species in Semiarid Mediterranean Prairies. Applied and Environmental Microbiology, 78, 6180-6186. http://dx.doi.org/10.1128/AEM.01287-12

[24] Alguacil, M.M., Torrecillas, E., Hernández, G. and Roldán, A. (2012) Changes in the Diversity of Soil Arbuscular Mycorrhizal Fungi after Cultivation for Biofuel Production in a Guantanamo (Cuba) Tropical System. PLoS ONE, 7, e34887. http://dx.doi.org/10.1371/journal.pone.0034887

[25] Higo, M., Isobe, K., Kondo, T., Yamaguchi, M., Takeyama, S., Drijber, R.A. and Torigoe, Y. (2015) Temporal Variation of the Molecular Diversity of Arbuscular Mycorrhizal Communities in Three Different Winter Cover Crop Rotational Systems. Biology and Fertility of Soils, 51, 21-32. http://dx.doi.org/10.1007/s00374-014-0945-4

[26] Liu, Y., He, L., An, L.Z., Helgason, T. and Feng, H.Y. (2009) Arbuscular Mycorrhizal Dynamics in a Chronosequence of Caragana korshinskii Plantations. FEMS Microbiology Ecology, 67, 81-92. http://dx.doi.org/10.1111/j.1574-6941.2008.00597.x

[27] Isobe, K., Maruyama, K., Nagai, S., Higo, M., Maekawa, T., Mizonobe, G., Drijber, R.A. and Ishii, R. (2011) Arbuscular Mycorrhizal Fungal Community Structure in Soybean Roots: Comparison between Kanagawa and Hokkaido, Japan. Advances in Microbiology, 1, 13-22. http://dx.doi.org/10.4236/aim.2011.11003

[28] Phillips, J.M. and Hayman, D.S. (1970) Improved Procedures for Clearing Roots and Staining Parasitic VesicularArbuscular Mycorrhizal Fungi for Rapid Assessment of Infection. Transactions of the British Mycological Society, 55, 158-161. http://dx.doi.org/10.1016/S0007-1536(70)80110-3

[29] Giovannetti, M. and Mosse, B. (1980) An Evaluation of Techniques for Measuring Vesicular-Arbuscular Mycorrhizal Infection in Roots. New Phytologist, 84, 489-500. http://dx.doi.org/10.1111/j.1469-8137.1980.tb04556.x

[30] Liang, Z.B., Drijber, R.A., Lee, D.J., Dwiekat, I.M., Harris, S.D. and Wedin, D.A. (2008) A DGGE-Cloning Method to Characterize Arbuscular Mycorrhizal Community Structure in Soil. Soil Biology and Biochemistry, 40, 956-966. http://dx.doi.org/10.1016/j.soilbio.2007.11.016

[31] Helgason, T., Daniell, T.J., Husband, R., Fitter, A.H. and Young, J.P.W. (1998) Ploughing up the Wood-Wide Web? Nature, 394, 431. http://dx.doi.org/10.1038/28764

[32] Simon, L., Lalonde, M. and Bruns, T.D. (1992) Specific Amplification of 18S Fungal Ribosomal Genes from VesicularArbuscular Endomycorrhizal Fungi Colonizing Roots. Applied and Environmental Microbiology, 58, 291-295.

[33] Kowalchuk, G.A., de Souza, F.A. and van Veen, J.A. (2002) Community Analysis of Arbuscular Mycorrhizal Fungi Associated with Ammophila arenaria in Dutch Coastal sand Dunes. Molecular Ecology, 11, 571-581. 
http://dx.doi.org/10.1046/j.0962-1083.2001.01457.x

[34] Cornejo, P., Azcón-Aguilar, C., Miguel Barea, J. and Ferrol, N. (2004) Temporal Temperature Gradient Gel Electrophoresis (TTGE) as a Tool for the Characterization of Arbuscular Mycorrhizal Fungi. FEMS Microbiology Letters, 241, 265-270. http://dx.doi.org/10.1016/j.femsle.2004.10.030

[35] Yang, H.S., Zang, Y.Y., Yuan, Y.G., Tang, J.J. and Chen, X. (2012) Selectivity by Host Plants Affects the Distribution of Arbuscular Mycorrhizal Fungi: Evidence from ITS rDNA Sequence Metadata. BMC Evolutionary Biology, 12, 50. http://dx.doi.org/10.1186/1471-2148-12-50

[36] Broeckling, C.D., Broz, A.K., Bergelson, J., Manter, D.K. and Vivanco, J.M. (2008) Root Exudates Regulate Soil Fungal Community Composition and Diversity. Applied and Environmental Microbiology, 74, 738-744. http://dx.doi.org/10.1128/AEM.02188-07

[37] Husband, R., Herre, E.A., Turner, S.L., Gallery, R. and Young, J.P.W. (2002) Molecular Diversity of Arbuscular Mycorrhizal Fungi and Patterns of Host Association over Time and Space in a Tropical Forest. Molecular Ecology, 11, 2669-2678. http://dx.doi.org/10.1046/j.1365-294X.2002.01647.x

[38] Dumbrell, A.J., Ashton, P.D., Aziz, N., Feng, G., Nelson, M., Dytham, C., Fitter, A.H. and Helgason, T. (2011) Distinct Seasonal Assemblages of Arbuscular Mycorrhizal Fungi Revealed by Massively Parallel Pyrosequencing. New Phytologist, 190, 794-804. http://dx.doi.org/10.1111/j.1469-8137.2010.03636.x

[39] Veresoglou, S.D., Caruso, T. and Rillig, M.C. (2013) Modelling the Environmental and Soil Factors That Shape the Niches of Two Common Arbuscular Mycorrhizal Fungal Families. Plant and Soil, 368, 507-518. http://dx.doi.org/10.1007/s11104-012-1531-X

[40] Yasuda, K., Fujii, Y. and Shibuya, T. (1987) Difference of Plants Growth and Phosphorus Uptake at Low Phosphorus Condition. Japanese Society of Soil Science and Plant Nutrition, 58, 180-186.

[41] Yoneyama, T., Horie, H., Takebe, M. and Tanno, F. (1990) Absorption of Phosphorus from Soil by Crops: II. The Relationship between Root Mass and Phosphorus Absorption. Japanese Society of Soil Science and Plant Nutrition, 61, 382-385.

[42] Isobe, K. and Tsuboki, Y. (1998) The Relationship between Growth Promotion by Arbuscular Mycorrhizal Fungi and Root Morphology and Phosphorus Absorption in Gramineous and Leguninous Groups. Japanese Journal of Crop Science, 67, 347-352. http://dx.doi.org/10.1626/jcs.67.347

[43] Taffouo, V.D., Ngwene, B., Akoa, A. and Franken, P. (2014) Influence of Phosphorus Application and Arbuscular Mycorrhizal Inoculation on Growth, Foliar Nitrogen Mobilization, and Phosphorus Partitioning in Cowpea Plants. Mycorrhiza, 24, 361-368. http://dx.doi.org/10.1007/s00572-013-0544-5

[44] Scheublin, T.R., Ridgway, K.P., Young, J.P.W. and van der Heijden, M.G.A. (2004) Nonlegumes, Legumes, and Root Nodules Harbor Different Arbuscular Mycorrhizal Fungal Communities. Applied and Environmental Microbiology, 70, 6240-6246. http://dx.doi.org/10.1128/AEM.70.10.6240-6246.2004 
Scientific Research Publishing (SCIRP) is one of the largest Open Access journal publishers. It is currently publishing more than 200 open access, online, peer-reviewed journals covering a wide range of academic disciplines. SCIRP serves the worldwide academic communities and contributes to the progress and application of science with its publication.

Other selected journals from SCIRP are listed as below. Submit your manuscript to us via either submit@scirp.org or Online Submission Portal.
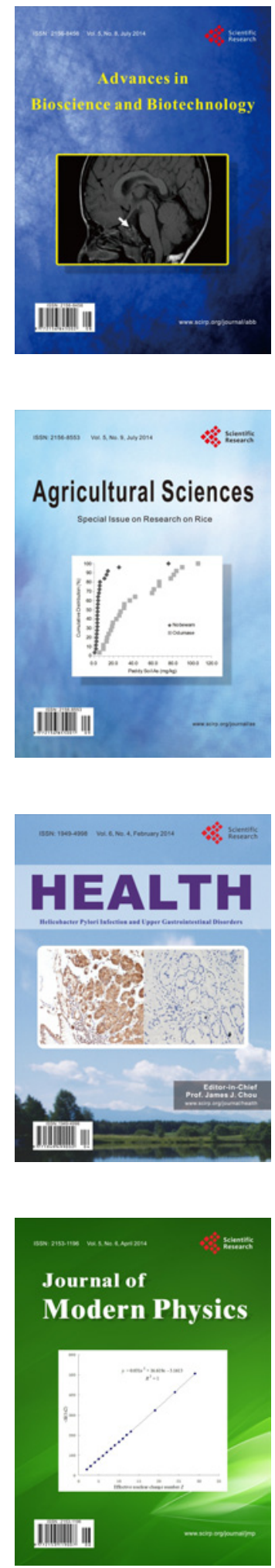
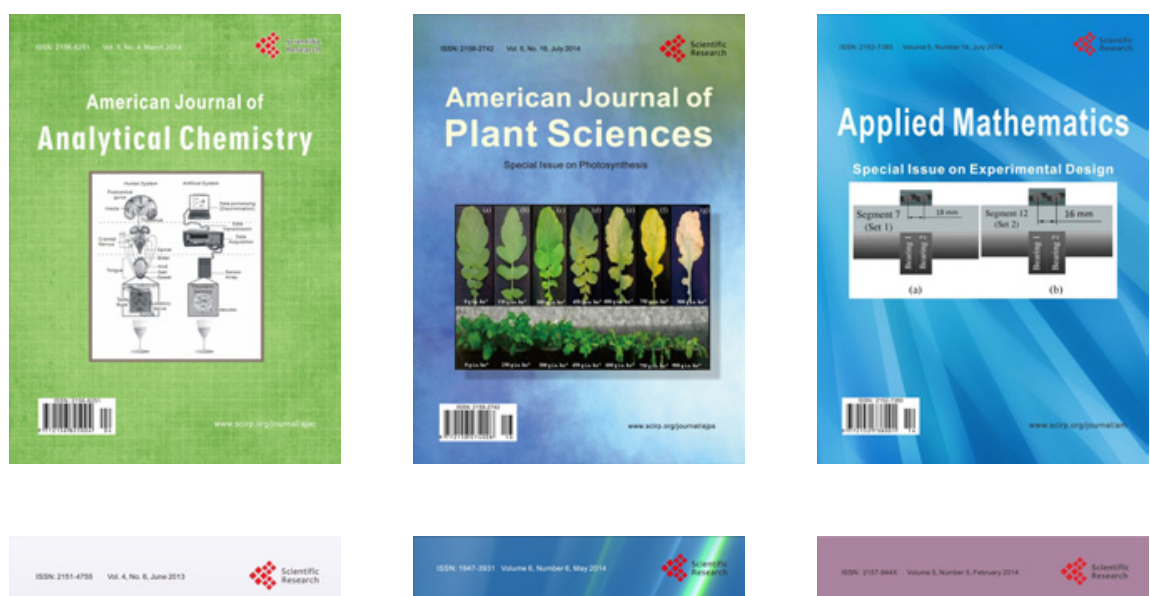

Creative Education
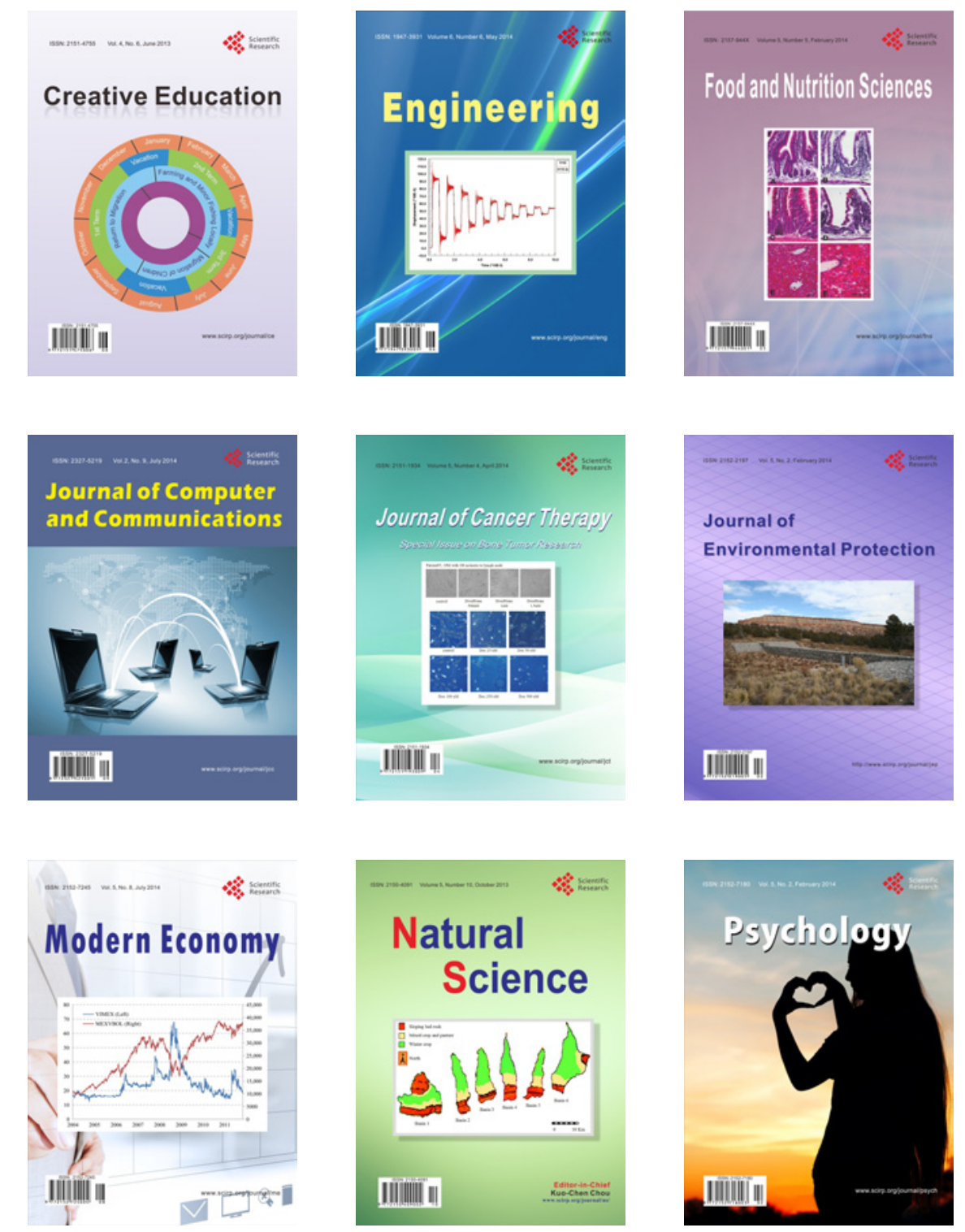